\title{
CURRENCY ASPECTS OF FINANCIAL SECURITY OF THE BANKING SYSTEM OF UKRAINE: REGULATORY PRIORITIES AND TRANSFORMATION OF CONTROL
}

\author{
Oleksandra Vasylchyshyn \\ Department of Taxation and Fiscal Policy, \\ Ternopil National Economic University, \\ 11 Lvivska str., Ternopil, Ukraine, 46020 \\ volexandra@gmail.com
}

\begin{abstract}
The article is devoted to the topical subject - the study of currency aspects of the financial security of the banking system of Ukraine, taking into account the threats of liberalization of cross-border capital transfer and currency regulation. The main objectives of the article are studying the main threats to the currency security of the banking system of Ukraine in the context of the transformation of currency control within the liberalization of currency relations. In particular, the study found that currency security is one of the main components of the financial security of the banking system, and exchange rate instability is one of the greatest threats to the effective functioning of Ukrainian banking institutions, taking into account the peculiarities of the national structure of financial assets and liabilities of business entities. As a result, it is found that the deterioration of the exchange rate stability leads to a revaluation of assets, the outflow of foreign currency deposits from banks, which leads to their loss and significant deterioration of financial security, while a decrease in the volume of gold and foreign exchange reserves directly affects the currency security of the state, in particular, and the economic in general. Based on the research results, proposals have been made to improve currency regulation and currency control, namely, amendments to the draft law should be made with regard to the administrative restriction of the dollarization level of deposits and credits, indicating the terms for reducing the dollarization rates of loans and deposits from $50 \%$ to $20-25 \%$. The mechanism for such reduction in dollarization should be included in the instruments of the National Bank of Ukraine, namely, the norm of mandatory reservation for deposits in foreign currency should be 3-4 times higher than the reserve rate in the national currency, which will make foreign currency deposits "uninteresting" for banks, and therefore will lead to a reduction in the interest rate and, accordingly, reduce the desire to save in foreign currency. By dollarization of loans, the credit risk reservation ratio should also be significantly higher than in the national currency in order to demobilize banks for lending in foreign currency, an exception can only be for those enterprises that carry out foreign economic activity. In addition, lending to individuals for all types of loans in foreign currency should be banned, and the fact of such ban should be clearly spelled out in the Law on Currency. This will prevent the outflow of capital from the state and form a mechanism to reduce the scale of the shadow foreign exchange market as the main threats to the currency and financial security of the banking system of Ukraine.
\end{abstract}

Keywords: currency security, currency liberalization, financial security of a threat, currency control, currency regulation.

\section{Introduction}

The globalization of international economic relations dictates its rules of interaction between countries. In the sphere of currency regulation and control, this is expressed in the general trend towards a certain liberalization of the procedure for the implementation of current foreign exchange operations.

Interstate and international treaties and agreements concerning the streamlining of cross-border foreign exchange transactions, as well as the need to prevent and mitigate the effects of possible future crisis in the monetary sphere, impose certain restrictions on the range of tools and techniques that can be used to achieve monetary policy objectives.

The great importance of the international factor in the regulation of currency relations by the countries is due, first of all, to the growing interdependence and vulnerability of national economies in the context of the globalization of international economic relations and the high mobility of capital.

Today, the impact of the world financial system on individual countries is being implemented at a qualitatively different level, taking into account the exclusivity of the monetary and financial component in the economy. That is why in the structure of national economic security an important role is assigned to monetary and financial instruments and the nature of their use. 
The monetary and financial security of the state is achieved by an appropriate level of stability in the economic development of the state, its banking system, monetary and currency policies. In addition, it is supported by the state's ability to withstand financial crises. In many ways, it depends on the ability to prevent large-scale capital flight abroad, as well as its leakage from the real economy.

Currency regulation is traditionally regarded as one of the most important instruments of influence on economic relations, due to the mutual conditioning of processes in the monetary and financial spheres and the economy as a whole.

The choice of forms and methods of currency regulation depends on certain factors, in particular: the conditions of the economic situation of the country, the state of the monetary system, the level of legislative regulation of individual components of currency relations. In this regard, it is possible to single out a single reference model of currency regulation, meets the requirements of each individual country.

That is why the problem of finding those mechanisms of currency regulation and currency control that would be most adequate to the present stage of development of the domestic economy in the plane of raising the level of financial security of the national banking system comes to the fore. Additional complexity in the creation of a coherent and secure system of currency regulation and exchange control creates the complex nature of these relations. Moreover, in the conditions of the economic crisis, the improvement of control over the implementation of currency transactions acquires extreme urgency.

Politics and currency regulation in the national scientific thought is devoted to quite a lot of publications. Thus, in particular, scientists such as A. Krysovatyi, A. Fedosov, A. Drobiazko note that the crisis phenomena during 2008-2015 still affect the state of the banking and currency system of Ukraine, characterized by a decrease in the confidence of households and the corporation in national currency [1]. So, in particular, A. Dzyublyuk notes that the choice of the optimal exchange rate regime should be considered one of the key tasks of the monetary policy both at the national and global levels, since an adequate monetary policy of the central bank is only able under such conditions to effectively counter external shocks in the global financial environment [2]. Also, scientist O. Bereslavska, in studies on currency regulation, warns that Ukraine needs a stable exchange rate dynamics to overcome crisis phenomena, which must be achieved by market methods, since others, as the twenty-year domestic experience shows, are ineffective (and this task is impossible only at the expense of announcement of the benchmarks for one year). To ensure that foreign exchange markets do not react to the slightest fluctuations in the market situation, banks, enterprises and the public should see and understand the long-term policy of monetary authorities [3]. A. Klimenko in study emphasizes that for the effective implementation of monetary policy in the context of the globalization of economic processes, it is necessary to implement currency regulation in accordance with the state of the country's economic development, ensure minimization of the negative impact of internal and external shocks and contribute to its sustainable economic development. At the same time, an important task for the NBU is the development of a medium-term monetary policy strategy with a clear definition of the benchmarks, tools for ensuring currency stability [4]. T. Kosova and I. Steblianko in their studies determine that the sharp depreciation of the national currency in 2014 was due to the double deficit of the balance of payments of Ukraine and its structure associated with a large proportion of exogenous items. They also negatively assess the trends associated with the rapid decline in exports for all major groups of goods, while the positive features of the monetary policy are highlighted by the reduction of the country's dependence on imports, primarily energy, which manifests itself in excess of the reduction in import volumes over exports, reducing the current account deficit in the balance of payment ensuring a surplus of the balance of payments [5]. M. Demidenko argues that the de-dollarization catalysts for can be specific macroprudential measures aimed at limiting the exposure of foreign currencies to unoccupied borrowers, prohibiting the most risky types of lending in foreign currency, reducing the use of foreign currency in settlements between residents, detaching tax rates (duties, rents, tariffs and other payments) for the US dollar and the euro, returning to differentiated reserve requirements and providing indirect regulation of attractiveness of ruble and foreign currency deposits [6]. 
However, the problem of currency security, and even more the currency aspects of the financial security of the banking system of Ukraine remains unrevealed, which requires the formation of new approaches to the study of the monetary and financial sphere in our country.

\section{Aim of research}

Investigation of the main threats to currency aspects of the financial security of the banking system of Ukraine in the context of the transformation of currency control within the liberalization of currency relations for taking preventive measures to ensure the stability of the functioning of the banking system of Ukraine.

\section{Materials and method}

Foreign experience shows that the development of currency relations, the domestic foreign exchange market occurs with the active regulatory role of the state and effective control over foreign exchange operations by authorized bodies.

The effectiveness of the system of currency regulation and currency control is the most important factor in ensuring the stability of the national currency, the stability of the financial and credit system and the financial market, the formation of the investment climate in the country, the development of international economic integration in particular, and the financial security of Ukraine as a whole.

The stability of the functioning of the economy, the guarantee of the country's economic and financial security is to a large extent conditioned by the situation of currency regulation and currency control. Currency regulation is one of the fundamental directions of state regulation of the economy, defined as the procedure for the impact of state power on public relations in order to regulate and stabilize them.

The state implements currency regulation through the formation and legislative enactment of rules and procedures for the execution of foreign exchange transactions. Such implementation of the appropriate framework for currency relations is necessary to achieve many goals, in particular: maintaining a constant exchange rate of the national currency, effective functioning of the monetary and financial mechanism of the state, maintaining and strengthening a stable balance of payments, preventing and suppressing offenses in monetary and financial relations.

In the process of integrating the domestic economy into the European economic area, state currency regulation is important for maintaining balance of payments equilibrium, preventing capital outflow and ensuring the inflow of foreign investment, as well as protecting the domestic foreign exchange market from the negative impact of foreign speculative capital. In addition, currency regulation should not impede the development of interstate economic relations, including the effective allocation of capital and a reduction in the investment attractiveness of the economy.

The main parameter of the state's ability to implement an independent financial and economic policy in accordance with its national interests is its financial security. This security is due to the ability of state agencies to avoid the stability of state development against [7]:

- an impact of global financial crises;

- deliberate actions of participants in global financial and economic relations (states, transnational corporations, etc.);

- an influence of shadow structures on the national economic and socio-political system, the spread of crimes and administrative offenses in the financial sphere, in particular, the legalization (laundering) of proceeds from crime;

- significant capital outflow abroad;

- "capital outflow" from the real sector of the economy.

That is why, from the point of view of economic relations, currency security is understood as a state of exchange rate formation that creates optimal conditions for the progressive development of domestic exports, unhindered inflow of foreign investments into the country, integration of Ukraine into the world economic system, and also protects against shocks in international currency markets. The main indicator of currency security is the exchange rate of the national currency $[8$, p. 41]. 
At the same time, the strategy of ensuring foreign exchange security of Ukraine, according to some researchers, should cover such measures as [9, p. 53]:

- improving the regulatory framework;

- increasing the level of responsibility of the National Bank of Ukraine;

- increasing transparency in the monetary sphere;

- improving the international reserves management system;

- development and implementation of information methods of influence of the National Bank of Ukraine on the monetary policy of private entities of currency legal relations;

- development of progressive monetary liberalization of capital flows;

- strengthening of market mechanisms of self-organization of the currency market;

- formation of interest rate management mechanisms.

The Methodological Recommendations on the calculation of the level of economic security of Ukraine explains the concept of "currency security" as a state of exchange rate formation, characterized by high public confidence in the national monetary unit, its stability, creating optimal conditions for the progressive development of the domestic economy, attracting foreign investment, of the world economic system, and also protects as much as possible from shocks in the international currency markets [10]. However, the interpretation of the term "currency security" is absent in the current Decree of the Cabinet of Ministers of Ukraine "On the system of currency regulation and currency control" [11], which, in turn, creates a certain legal collision. In addition, there is no classification of currency transactions in this document, there are no specific goals, directions, forms, types of currency control, the competence of government bodies in the area of currency regulation and control is not clearly defined, and there is some overlap in other legislative acts, causes ambiguous interpretation problems of separate provisions.

That is why it is strategically important to clearly define the regulatory priorities and dominants of controlling foreign exchange security. It is necessary to establish factors directly affecting its level. At the same time, in our opinion, it is necessary to distinguish between the currency security of the state, the currency security of subjects, the currency security of commercial banks and the currency security of the society.

A special place in the gradation of levels of currency security should be taken by the currency security of the banking system as its ability to withstand threats caused by sharp changes in the exchange rate, changes in the conditions for currency transactions, changes in the demand for foreign currency deposits and the like.

Currency security is one of the main components of the financial security of the banking system, and exchange rate instability is one of the greatest threats to the effective functioning of Ukrainian banking institutions, taking into account the peculiarities of the national structure of financial assets and liabilities of business entities. Therefore, any deterioration in exchange rate stability leads to a revaluation of assets, the outflow of foreign currency deposits from banks, which leads to their loss and significant deterioration of financial security, while a decrease in the volume of gold and foreign currency reserves directly affects the currency security of the state, in particular, and economic in general.

Thus, the development of new methods for regulating the currency market of Ukraine or improving existing ones should take into account the main directions of accumulation of threats for the stable functioning of the banking system, as the main link of the economy. Let's consider in detail each of them.

1. Dollarization of the economy and the shadow foreign exchange market. Dollarization of the economy is an internal threat to the currency and financial security of the banking system of Ukraine, since its level is formed on the basis of gaps in the legal field of banking operations. Ineffective regulatory requirements and bank supervision of foreign currency transactions and deposit-credit activities of banks lead to the accumulation of significant amounts of assets and liabilities in foreign currency that, during political or economic instability, become the object of rush demand for foreign currency and, as a consequence, the main direction of manifestation of currency risks.

In the economic literature and in the legal plane, there are two types of dollarization of the economy: official and unofficial. The official dollarization of the economy assumes the official 
granting of the national currency status to foreign currency along with a complete replacement of all settlements and savings in the national currency with foreign currency. Unofficial dollarization reflects the process of the displacement of foreign currency by national currency in terms of calculations and savings by partially performing such functions of foreign currency as money, a means of circulation and a means of accumulation. Unofficial dollarization is divided into three types:

1) dollarization of payments - foreign currency is used as a means of payment (serves as a means of circulation);

2) financial dollarization - residents of the country have financial assets in foreign currency (performs the function of accumulation);

3) real dollarization - prices and/or salaries are set in foreign currency (fulfills the function of a measure of value).

Each of the types of dollarization has its own calculation formula. Let's calculate the dollarization level of the national economy based on the availability of statistical data (Table 1).

Table 1

The main indicators of dollarization of the economy and the banking system of Ukraine, $\%$ *

\begin{tabular}{ccccccccc}
\hline Indicator name (year) & $\mathbf{2 0 1 0}$ & $\mathbf{2 0 1 1}$ & $\mathbf{2 0 1 2}$ & $\mathbf{2 0 1 3}$ & $\mathbf{2 0 1 4}$ & $\mathbf{2 0 1 5}$ & $\mathbf{2 0 1 6}$ & $\mathbf{2 0 1 7}$ \\
\hline Dollarization of the money supply & 29,7 & 31,0 & 32,7 & 27,4 & 32,4 & 32,7 & 33,3 & 33,7 \\
dollarization of deposits & 42,6 & 43,0 & 44,0 & 37,0 & 45,9 & 45,3 & 46,3 & 45,4 \\
dollarization of credits & 46,0 & 40,3 & 36,7 & 33,8 & 46,3 & 55,8 & 49,4 & 43,9
\end{tabular}

Note: *-Calculated by the author according to the data of the NBU [12]

As can be seen from Table 1, a third of the money supply in Ukraine is dollarized, but it should be noted that when analyzing the dollarization of the money supply, in the absence of statistical data, it is not possible to take into account the volume of cash currency, reduces the calculated figure. However, according to experts, the dollarization of the cash supply in Ukraine is about $60 \%$ [13], reflects the level of confidence in the national currency in the society and is one of the main reasons for the rush demand for foreign currency in conditions of deteriorating the situation in the country.

In addition, it is worth noting the high level of dollarization of deposits and loans of the domestic banking system, in the conditions of the deterioration of exchange rate stability is expressed in significantly greater losses for the Ukrainian economy as a result of revaluation of assets and reserves for active operations.

Thus, taking into account that half of deposits and credits of the banking system of Ukraine is dollarized, de-dollarization of bank assets and liabilities should become one of the main measures of currency regulation and control, however such measure was not reflected in the draft Law of Ukraine "On currency" [14]. The flexible exchange rate, which is indicated as one of the principles of currency regulation of the new law "On Currency" will not be able to solve the problems of dollarization, and creeping devaluation of the national currency will be one of the factors reducing the profitability of the banking system as a result of revaluation of assets, credits.

Therefore, in our opinion, in this context, it is necessary to amend the draft law "On currency" in terms of administrative restrictions on the dollarization level of deposits and loans, indicating the time frame for reducing the dollarization rates of loans and deposits from $50 \%$ to $20-25 \%$. The mechanism for such reduction in dollarization should be included in the instruments of the National Bank of Ukraine, namely, the norm of mandatory reservation for deposits in foreign currency should be 3-4 times higher than the reserve rate in the national currency, which will make foreign currency deposits "uninteresting" for banks, and therefore will lead to a reduction in the interest rate and, accordingly, reduce the desire to save in foreign currency. By dollarization of loans, the credit risk reservation ratio should also be significantly higher than in the national currency in order to demobilize banks for lending in foreign currency, an exception can only be for those enterprises that carry out foreign economic activity. In addition, lending to individuals for 
all types of loans in foreign currency should be banned, and the fact of such ban should be clearly spelled out in the Law on Currency.

In this case, the dollarization level of the economy will be reduced, but there is a risk of outflow of currency funds from the banking system to the shadow foreign exchange market, it should also be resolved in the law "On currency". It is worth noting that there are no measures to limit the shadow exchange market, which is 80-90 billion dollars [15], and the content of possible restrictions of the National Bank of Ukraine is vague.

Undoubtedly, the scale of the shadow market of the currency can be reduced by creating favorable conditions for economic development and business (one of the factors of the shadowing of currency transactions is the tax burden and administrative and corruption rent), but the established traditions of the functioning of the shadow foreign exchange market must also be broken by administrative methods in the form of sanctions, fines and criminal prosecution.

2. Stable-negative balance of payments. Despite the fact that the national economy is small, open and resource-based economy with a low level of innovation and technological structure, Ukraine has a consistently negative balance of payments equalization which occurs only in the event of devaluation surges. The predominance of imports of goods over exports, together with a low volume of foreign investment and threats of the withdrawal of capital, exerts a devaluation pressure on the stability of the national currency. This situation requires a change in the concept of exchange rate formation and regulation of cross-border capital flows, which, incidentally, is the basis of the new law "On Currency" under the guise of monetary liberalization. It should be noted that the idea of monetary liberalization is good for developed countries of the world, however, for such economy as in Ukraine, currency liberalization may become the beginning of the end, in spite of those high sovereign risks, our country is unlikely to be able to count on long-term foreign investments, short-term speculative capital, which, due to the slightest change on the political or economic background, will immediately leave the country is quite realistic. On the other hand, the liberalization of the capital movement from Ukraine abroad by its nature and consequences can be equated with the introduction of a visa-free regime, when the majority of the economically active population went abroad to earn money. Liberalization of capital flows is likely to lead to an outflow of capital from Ukraine to those countries where risks are lower and where there is a high potential for economic growth, for example, in Poland.

Part of the problem of the negative balance of payments can be solved on the one hand by stimulating the inflow of foreign investment, and on the other - by minimizing the channels for the withdrawal of capital.

So, as for the directions of stimulating the inflow of foreign investments, in our opinion, it is possible to take advantage of Poland's experience with regard to preferential taxation of foreign investors regarding the formation of tax supervision over currency transactions in Ukraine.

Thus, for development of the industrial sector and the regulation of the balance of payments, direct grants to Polish foreign investors in Poland are provided for the creation of special economic zones (SEZ is the area defined by legal acts of the Ministry of Economy of Poland, in which special support is provided for the development of local infrastructure and provision of benefits in form of exemption from payment of profit tax from the capital of the enterprise). The main task of granting state subsidies within the SEZ is to ensure the development of economically backward regions of the country. To receive tax benefits, the investor is required to obtain a special permit issued by the management body of such zone. To conduct business within the special economic zone, there are certain conditions, namely: the cost of investment should be at least 100 thousand EUR, as well as no less than 5 years (for medium and small businesses - at least 3 years) should not be taken out of investments and the reduction of created jobs is excluded. The investor is given the opportunity to receive a guaranteed benefit in the form of exemption from corporate income tax. It is provided in accordance with two articles, namely: for new investments or creation of new jobs (the entrepreneur has the right to choose the privilege that he wants to use). The use of the benefit for new investments assumes the adoption of the maximum amount of assistance with qualified investment costs, the definition and calculation of which is approved by the decree of the Council of Ministers of Poland. An obligatory condition for obtaining such benefit is the investing of own capital by 
the investor in the amount of at least $25 \%$ of the total investment costs (the minimum amount of investments remains unchanged (100 thousand EUR).With using the benefit to create new jobs, the calculation of the amount is based on two-year costs for payment for new employees (the amount of assistance may vary according to the size of the enterprise from $50 \%$ to $70 \%$ ) [16, p. 182-183].

Such mechanism to stimulate the flow of foreign investors along with the liberalization of capital flows to Ukraine will undoubtedly have a positive effect on the balance of payments, exchange rate stability, growth of official reserve assets, and will lead to the inflow of long-term resources into the banking system, in aggregate will have a positive impact on the financial security of the banking system.

3. Capital «outflow» - the withdrawal of foreign exchange assets abroad. Full liberalization of the capital movement (all transactions are allowed, not directly prohibited by law) can increase the already significant capital outflow from Ukraine (Fig. 1).

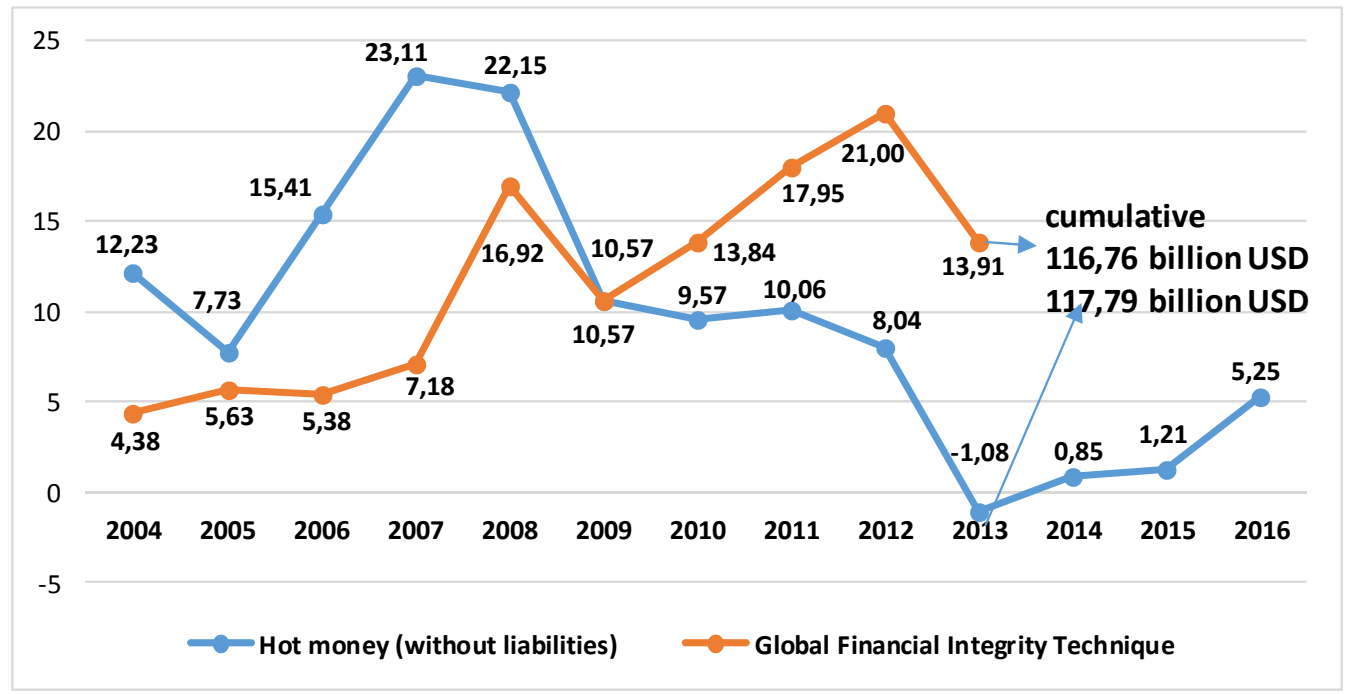

Fig. 1. The dynamics of illegally withdrawn capital calculated using the Global Financial Integrity method and "hot money" * - Calculated by the author according to Global Financial Integrity [17] and NBU [12]

The main channels for the capital outflow from Ukraine are the following three:

1) the actual outflow of capital, which reflects the objective process of capital withdrawal by foreign investors (However, foreign firms, where the main beneficiaries are natural persons-citizens of a given country) are the deterioration of the economic situation in the country;

2) export of capital - investments from one country to another, except for investments in companies that are related persons of national investors;

3) withdrawal of capital, movement of financial resources across the state border by certain individuals or legal entities with a view to avoiding taxation or controlling procedures of financial control and monitoring bodies through transfer pricing, money transfers, foreign investment.

As for the specified directions of capital flows outside Ukraine, the draft law "On Currency" does not specify a mechanism for investing abroad, it is obvious that such norm should be regulated by the National Bank of Ukraine in the form of currency restrictions that can be introduced for no more than six months. In our view such rule is quite contradictory, because such currency restrictions, in fact, can be perpetual, if the previous restrictions are canceled for 1 day, and the next day introduced again. What will happen in case of cancellation of foreign exchange restrictions on investments abroad, permission to invest without restrictions, similar to cross-border movement of currency values by legal entities?

Today, the mechanism for investment abroad is determined by individual NBU licenses in accordance with the Instruction of the NBU "On the procedure for issuing individual licenses for investment abroad", which provides that the amount of transactions for investment abroad within 
one individual license during one calendar year should not exceed 2 million USD (the equivalent of this amount in another currency at the official exchange rate of the hryvnia against foreign currencies set by the National Bank of Ukraine on the transfer date). The existence of such restriction, in our opinion, is justified from the point of view of the specifics of domestic investments outside the country. This specificity consists in the direction and ways of investing. So, the lion's share of investments from Ukraine falls on offshore zones (Fig. 2), which means not investment in the full sense of the word, but the withdrawal of capital outside the country.

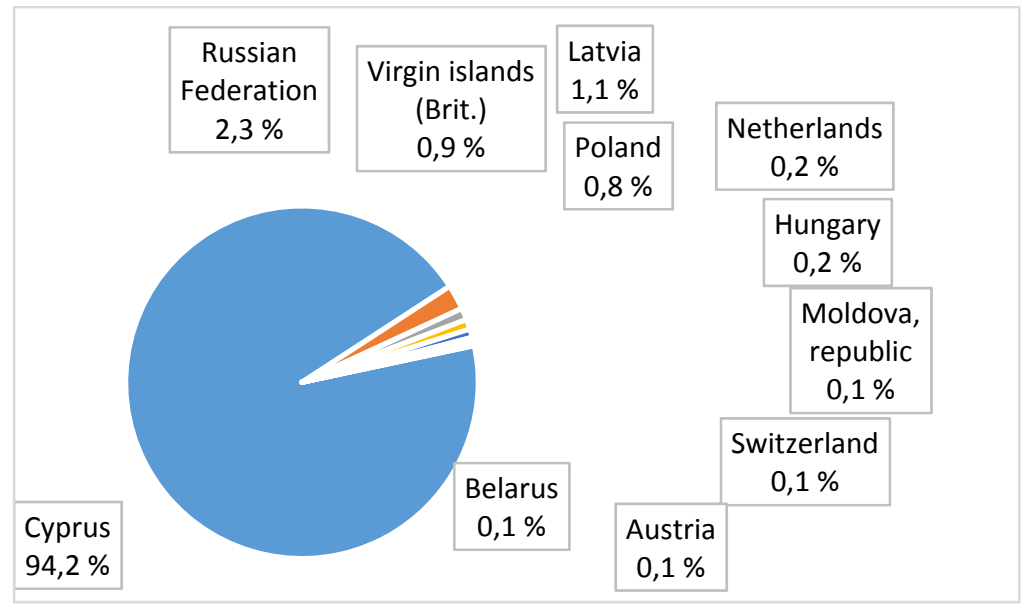

Fig. 2. The structure of direct investment (equity and debt instruments) from Ukraine abroad as of December 31, 2017. Calculated by the author according to [18]

As can be seen from the figure, $94.2 \%$ of direct investment of 5.9 billion USD from Ukraine abroad is carried out to Cyprus and the Virgin Islands, which are offshore zones. In case of complete liberalization of cross-border capital flows, the risk of increasing such investments in offshore zones in order to avoid or reduce taxation. Such risks are manifested in two ways: firstly, the growth of investment abroad in offshore zones indicates the withdrawal of funds from Ukraine by its citizens and not by non-residents, in the face of financial or political problems, lead to a huge outflow of currency outside the state (Fig. 1), and this, in turn, will lead to imminent devaluation and, as a result, the next crisis of the banking system and the deterioration of its financial security; secondly, the growth of foreign investment abroad for the purpose of tax evasion will significantly reduce the revenues of the state budget, will have negative consequences for the economy as a whole through the debt channel. Therefore, in such circumstances, complete liberalization of capital flows is unacceptable for Ukraine even if the National Bank of Ukraine is granted broad powers for currency restrictions, since the low level of its independence casts doubt on the effectiveness of such restrictions and the effectiveness of punishment for their violation for various financial and industrial groups of our country.

Thus, today there is an urgent need to create a clear and understandable mechanism for all transboundary movement of capital outside Ukraine in order to prevent the outflow of foreign exchange from the interbank foreign exchange market and the banking system as a whole, which may lead to a significant reduction in its financial security. One such measure may be the creation of a separate section in the Law on Currency, entitled "Regulation of Foreign Investments", where it is necessary to prescribe clear restrictions on investments outside Ukraine and clear penalties for violation of this restriction.

4. Low level of official reserve assets. The consequence of the above mentioned directions of accumulation of threats to the currency and financial security of the banking system is the low level of official reserve assets, which reduces the ability of the National Bank of Ukraine to effectively respond to devaluation shocks. Solving the problems of accumulation and maintenance on the level of official reserve assets necessary to cover the import lies in the plane of regulating the cross-border movement of capital, minimizing the scale of the foreign exchange market and stimu- 
lating foreign investment. Thanks to such measures, the National Bank of Ukraine will be able to replenish its official reserve assets.

Thus, summing up the above, it is possible to conclude that it is necessary to revise the currency legislation of Ukraine, and in particular the draft law "On Currency", as the basis for the currency security of the state, the banking system, enterprises and society. The new law "On Currency" should provide the basis for the functioning of the foreign exchange market, cross-border movement of capital and foreign investment in order to minimize the negative effects on the stability of the national currency on which the financial security of banks and enterprises depends, as well as the welfare of the population.

In this context, public authorities and the National Bank of Ukraine need to be wary of recommendations and requirements of the International Monetary Fund and other donors of Ukraine, have a direct interest in increasing the openness of the national economy in order to use it as a raw material appendage of gaming and platforms. The basis for the currency legislation of Ukraine should be the requirement to ensure the financial security of the banking system as a key link in the domestic economy, the requirements to ensure the stability of the national monetary unit and the development of innovative economy by attracting direct long-term foreign investment. Threats and the desire for excessive withdrawal of capital need to be limited and regulated, already proposed by the tax on the withdrawn capital.

Prospective areas of research in this area should be research on reducing the size of the shadow exchange market, increasing the amount of official reserves and forming an effective exchange rate system in the context of the impact on the financial stability and reliability of the Ukrainian banking system.

\section{Discussion of results}

In order to the aim, it is possible to emphasize the urgency and necessity of constantly investigating possible threats to currency aspects of the financial security of the banking system of Ukraine. This analysis of the identification of major threats has allowed the formation of valuable proposals for improving foreign exchange regulation and currency control, namely the need to immediately make adjustments to the draft law with regard to the administrative restriction of the level of dollarization of deposits and loans, indicating the time periods for reducing the dollarization rates of loans and deposits from $50 \%$ to $20-25 \%$. The mechanism for such reduction in dollarization should be included in the instruments of the National Bank of Ukraine, namely, the norm of mandatory reservation for deposits in foreign currency should be 3-4 times higher than the reserve rate in the national currency, which will make foreign currency deposits "uninteresting" for banks, and therefore will lead to a reduction in the interest rate and, accordingly, reduce the desire to save in foreign currency. However, the effectiveness of implementing the latter in Ukraine requires further analysis, research and monitoring.

\section{Conclusions}

Summing up studies let's single out the following conclusions, firstly today need to make adjustments to the draft law "On currency" in terms of administrative limiting the level of dollarization of deposits and loans with a timetable reduce dollarization ratios of loans and deposits from $50 \%$ to $20-25 \%$. Of course, the mechanism for such reduction in dollarization should be included in the instruments of the National Bank of Ukraine, namely, the norm of mandatory reservation for deposits in foreign currency should be 3-4 times higher than the reserve rate in national currency, which will make foreign currency deposits "uninteresting" for banks, and consequently will lead to a reduction in the interest rate and, accordingly, reduce the desire to save in foreign currency.

Secondly, by dollarization of loans, the credit risk reservation ratio should also be significantly higher than in the national currency in order to demobilize banks for lending in foreign currency, an exception can only be for those enterprises that carry out foreign economic activity. In addition, lending to individuals for all types of loans in foreign currency should be banned, and the fact of such ban should be clearly spelled out in the Law on Currency. 
Thirdly, today there is an urgent need to create a clear and understandable mechanism for all cross-border movement of capital outside Ukraine in order to prevent the outflow of foreign exchange from the interbank foreign exchange market and the banking system as a whole, which may lead to a significant reduction in its financial security. One such measure may be the creation of a separate section in the Law on Currency, entitled "Regulation of Foreign Investments", where it is necessary to prescribe clear restrictions on investments outside Ukraine and clear penalties for violation of this restriction.

Fourthly, the basis for the currency legislation of Ukraine should be the requirement to ensure the financial security of the banking system as a key link in the domestic economy, the requirements to ensure the stability of the national monetary unit and the development of innovative economy by attracting direct long-term foreign investment. Threats and the desire for excessive withdrawal of capital need to be limited and regulated by already proposed the tax on the withdrawn capital.

\section{References}

[1] Drobyazko, A., Krysovatyy, A., Fedosov, A. (2015). Paradigm of the Development of Banking Infrastructure of Ukraine. Journal of global economy review, 1 (4), 4-14.

[2] Dziubliuk, O. V. (2013). Rehuliatyvnyi mekhanizm valiutnoi polityky v period kryzovykh yavyshch na finansovykh rynkakh. Svit finansiv, 1, 7-17.

[3] Bereslavska, O. I. (2013). Dysbalansy valiutnoho rynku Ukrainy. Visnyk NBU, 3, 3-19.

[4] Klymenko, O. M. (2014). Instrumenty realizatsiyi valiutnoi polityky NBU. Naukovyi visnyk Akademiyi munitsypalnoho upravlinnia. Seriya: Ekonomika, 1, 80-88.

[5] Kosova, T. D., Steblianko, I. O. (2016). Valiutna polityka ta struktura platizhnoho balansu Ukrainy: dialektyka vzaiemozviazku. Ekonomika ta derzhava, 2, 9-12.

[6] Lekar, S. I. (2014). Finansova bezpeka Ukrainy yak pidgruntia natsionalnoi bezpeky derzhavy. Aktualni pytannia finansovoi bezpeky derzhavy, 19-22.

[7] Demidenko, M. (2017). Dollarization: causes and solutions. Eurasian Development Bank. Available at: https://eabr.org/en/press/comments/dollarization-causes-and-solutions/

[8] Ilychok, B. I. (2017). Valiutna bezpeka Ukrainy - stan ta perspektyvy vdoskonalennia. Ekonomika ta upravlinnia natsionalnym hospodarstvom, 2 (58), 40-45.

[9] Bryhinets, O. O. (2016). Pravove zabezpechennia valiutnoi bezpeky derzhavy yak strukturnoho elementa finansovoi bezpeky derzhavy. Prykarpatskyi yurydychnyi visnyk, 3(12), 51-54.

[10] Metodychni rekomendatsiyi shchodo rozrakhunku rivnia ekonomichnoi bezpeky Ukrainy. Ministerstvo ekonomichnoho rozvytku i torhivli Ukrainy. Available at: http://www.me.gov.ua/Documents/ List?lang=uk-UA\&tag=MetodichniRekomendatsii

[11] Pro systemu valiutnoho rehuliuvannia i valiutnoho kontroliu: Dekret Kabinetu Ministriv Ukrainy vid 19.02.1993 No. 15-93. Verkhovna Rada Ukrainy. Available at: http://zakon2.rada.gov.ua/laws/ show/15-93

[12] Ofitsiynyi sait Natsionalnoho banku Ukrainy. Available at: http://www.bank.gov.ua

[13] Zholud, O., Piontkivska, I. (2016). Dolaryzatsiya ta chornyi rynok valiuty v Ukraini: prychyny, obsiahy, naslidky dlia ekonomiky ta polityky. Tsentr ekonomichnoi stratehiyi, 19.

[14] Proekt Zakonu Ukrainy «Pro valiutu». Available at: https://bank.gov.ua/doccatalog/document?id=53357806 $\mathrm{nft} / \mathrm{op} / 171 /$

[15] Monetary policy in Dollarized Economies. Available at: http://www.imf.org/external/pubs/

[16] Sutormina, A. M. (2015). Valiutne rehuliuvannia u zabezpechenni ekonomichnoho rozvytku Ukrainy. Kyiv, 225.

[17] Global Financial Integrity. Available at: http://www.gfintegrity.org/

[18] Ofitsiynyi sait Derzhavnoi sluzhby statystyky. Available at: http://www.ukrstat.gov.ua/ 